\section{Scenic costume in modern art practices}

\author{
Shandrenko Olga, \\ https://orcid.org/0000-0001-5284-7252 \\ Candidate of Art History, \\ Associate Professor, \\ Kiev National University \\ of Culture and Arts, \\ Kyiv, Ukraine \\ shan.olga77@gmail.com \\ Simoniya Kristina, \\ Master of Design, \\ Kyiv National University \\ of Culture and Arts, \\ Kyiv, Ukraine \\ simoniyakrista@gmail.com
}

\section{Сценічний костюм в сучасних мистецьких практиках}

\section{Шандренко Ольга Миколаївна,} https://orcid.org/0000-0001-5284-7252 кандидат мистецтвознавства, доцент,

Київський національний університет культури і мистецтв, Київ, Україна shan.olga77@gmail.com

\author{
Сімонія Кристина Гулієвна, \\ студентка магістратури з дизайну, \\ Київський національний університет \\ культури і мистецтв, \\ Київ, Україна \\ simoniyakrista@gmail.com
}

\section{Abstract}

The aim of the research is to systematize and define the scenic costume in the context of contemporary artistic practices. The methodology of the research. In order to accomplish the following tasks the methods of systematization, classification and the complex art analyses were implemented. The scientific novelty. It is mentioned the position of the contemporary scenic costume at contemporary art practice: the theater, cinema, ballet, circurse art, sport sphere and advertising companies and other modern performances, happening and carnavals. The classification of the scenic costume variety is performed. It is fulfilled the classification of the scenic costume taking into consideration the artistic characteristics. Conclusions. As a result of the modern scenic arts analysis, it is defined the versatility and complexity of the scenic costume as a different type of design activity. It is determined that the scenic costume enters into different types of artistic practices and requires detailed artistic analysis in the context of design.

\section{Анотація}

Мета дослідження. Визначити та окреслити місце сценічного костюма в сучасних мистецьких практиках і провести систематизацію різновидів сценічного костюма. Методологія дослідження. 3 метою виконання поставлених завдань у ході дослідження було використано методи систематизації, класифікації та комплексного мистецтвознавчого аналізу. Наукова новизна. Означено місце сучасного сценічного костюма всучаснихмистецькихпрактиках:театрі, кіно, балеті, естрадно-цирковому мистецтві, спорті, рекламних кампаніях та інших сучасних видовищах, таких як перфоманс, хеппенінг, карнавал. Проведено систематизацію різновидів сценічного костюма за призначенням. Здійснено класифікацію сценічного костюма за образотворчими характеристиками.

Висновки. У результаті аналізу сучасних сценічних видів мистецтв виявлено багатогранність та складність сценічного костюма як окремого виду дизайнерської діяльності. Визначено, що сценічний костюм проникає в різні види мистецьких практик і потребує детального мистецтвознавчого аналізу в контексті дизайну. 


\section{Key words: Ключові слова:}

costume, scenic costume, design, imaginativity, types of scenic costume, artistic practices.

костюм, сценічний костюм, дизайн, образотворення, різновиди сценічного костюма, мистецькі практики.

Вступ 1 Сучасні інформаційні технології трансформували розуміння видовища і сцени в XX-XXI століттях. Телебачення, Інтернет стали важливим інструментом поширення мистецьких практик серед різних народів і культур. Вихід видовища на інший рівень комунікації розширив межі існування й розуміння сцени та глядача. Тобто «видовище XX ст. набуває нових конфігуративних ознак, постійно перебуває в динамічному русі, змінюється, «приватизується», стає камерним, домашнім, та водночас набуває ознак загальнопланетарних. Так, наприклад, споглядач, маючи контакт з відеозв'язком, стає учасником подій, що здійснюються в даний час на іншому боці земної кулі» (Шандренко, 2011). Сучасне видовище трансформувалось і проникло в різні напрямки мистецтв. Не винятком став й один з важливих складників сценічного дійства - мистецтво створення сценічного костюма.

\section{Мета 2
дослідження}

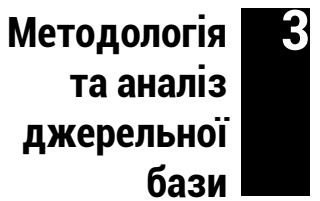

Метою дослідження передбачено визначення та окреслення місця сценічного костюма у сучасних мистецьких практиках, а також систематизацію різновидів сценічного костюма.

3 метою виконання поставлених завдань у ході дослідження було використано методи систематизації, класифікації та комплексного мистецтвознавчого аналізу.

Роботи, в яких піднімаються питання сценічного костюма, належать дослідникам різних галузей науки: історикам, культурологам, мистецтвознавцям. Значна кількість робіт має описовий огляд сценічного костюма в історичному контексті. Це, переважно, роботи таких вчених, як Р. Захаржевська (2009), Л. Кибалова та М. Ламарова (1987), К. Кіреєва (1970), М. Мерцалова (1993-2001), В. Березкін (1997), М. Олійник (2017) та ін. У наукових дописах сучасних дослідників зосереджено увагу на розгляді сценічного костюма в одному з видів мистецтв, зокрема, це роботи Д. Лідера (2004), Л. Березовчука та М. Вознесенского (1998) та ін. Проте, досліджень, в яких проведено систематизацію сценічного костюма в сучасних мистецьких практиках, не було виявлено.

\footnotetext{
Результати дослідження

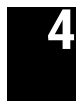

Значне місце серед сценічних костюмів займають театральні костюми. Це можуть бути костюми для театральної сцени, а також костюми для кіно. До такої роботи часто докладають руку вже відомі кутюр'є. Наприклад, костюми до кінострічки «П'ятий елемент» створював Готьє. Та навіть для дизайнера «з іменем» 
завдання створення театральних костюмів зовсім не є простим, адже, на відміну від «швидкоплинного» костюма на подіумі, костюм у кіно чи в театрі проживає ціле життя (Лідер, 2004).

Сценічний костюм $є$ важливим складником естрадно-циркових сцен, шоу, що відбуваються наживо, наче вистава: хореографічні або вокальні виступи, льодові шоу тощо. Кількість подібних дійств дуже велика, а робота над костюмами для них потребує неабиякого хисту, адже головне завдання таких шоу викликати бурну емоцію глядача, справити ефектне враження. Особлива задача костюму полягає у тому, щоб разом з виступом за досить короткий час донести максимум інформації глядачу і сприяти викладенню того, що хоче розказати артист на сцені. Циркове мистецтво найчастіше водночас поєднує у собі кілька видовищ. Так характеризує цей вид сценічного костюму С. Француз - художник з циркового костюму: «Добре відомо, наскільки велика роль костюма в драматичному або оперному театрі. Не менш важливий він і в цирку. Вдалий костюм виконавця допомагає глядачам найбільш повно сприйняти номер, надає цирковому видовищу яскраву святкову забарвлення» (Рыбкин, 2014). Звичайно для такого костюму є особливі вимоги залежно від номеру, який демонструється на арені.

Відмінно від попередніх, звичних сцен, можна розглядати сцену спортивного майданчику. Костюми спортсменів, які беруть участь у показових змаганнях, в першу чергу, повинні сприяти комфортному виступу конкурсанта, i, в той же час, мати необхідні естетичні характеристики. Дизайнер такого костюма має враховувати вид спорту, який буде демонструватися (фігурне катання, гімнастика, синхронне плавання тощо). Одяг конкурсантів має бути ергономічним, а також виразним та яскравим, підкреслювати красу рухів та тіла спортсмена. Часто він несе на собі і символічну функцію, ідентифікуючи країну, до якої належить людина.

Костюм дає чітке розуміння характеру персонажу, його настрій, особисті переживання є знаком комунікації. Таким чином посилює враження глядача від послуги, або товару, що рекламується. Це може бути: модний показ, музичний кліп, вуличний рекламний персонаж, рекламна компанія медіа формату тощо. Костюм здатен швидше і простіше для глядача донести інформацію, адже це ніби коротке повідомлення, що інформує повно, але не вербально. Так Ю. Андреєва про сучасні можливості передачі візуальної інформації зауважує, що все, що можна було б пояснити на словах, і в досить довгому повідомленні, нині передається блискавично. Символічна мова реклами робить ії доступною і, безумовно, виявляється успішною в інформаційно перевантаженому суспільстві (Андреева, 2006).

Сценічний костюм також має місце у сучасних видовищах, таких як хеппенінг, флеш-моб чи перфоманс. Отже, ми бачимо, що сучасне шоу вже не обмежується лише традиційною сценою театру. Тому ми пропонуємо розглядати сучасний сценічний костюм у контексті таких мистецьких практик, як театр, 
кіно, балет, естрадно-циркове мистецтво, спорт, рекламні кампанії, сучасні видовища (перфоманс, хеппенінг, карнавал) тощо.

Ми навмисно не включаємо до даного переліку костюм для обрядів та ритуалів, бо вважаємо, що ті соціальні ролі, які виконує людина в культурі під час таїнств хрещення, вінчання та інших, відбуваються не як сценічне дійство, а як певний етап ініціації, посвячення, як певний етап переходу та зміни.

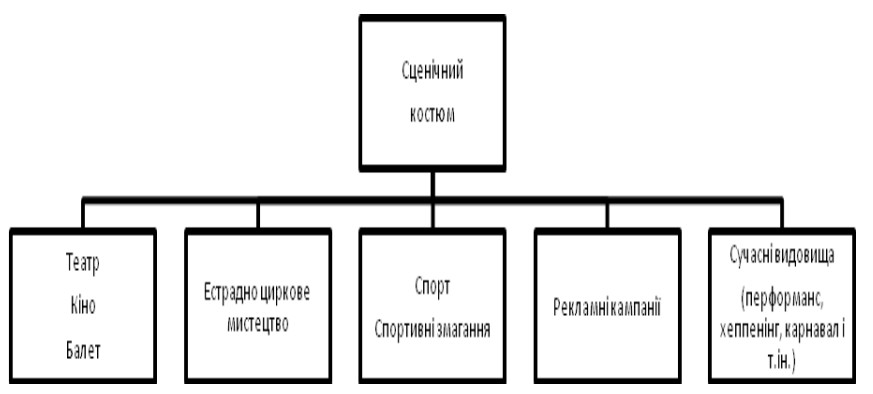

Рис. 4. 1. Сценічний костюм в контексті сучасних практик

Fig. 4.1. Stage costume in the context of modern practices

За своїм призначенням сценічний костюм можна розподілити на такі види: карнавальний, концертний (естрадно-цирковий), костюм для театру/кіно/балету, костюм для рекламних компаній та для спортивних змагань.

Карнавальний костюм дає змогу людині під час проведення заходу перевтілитись, у зв'язку з певними традиціями свята. Концертний (естрадно-цирковий) костюм або костюм для театру \кіно ббалету стає частиною того мистецтва, що демонструється, додає йому виразності. Костюм у рекламі існує як особливий засіб комунікації, швидке та чітке, виразне передавання інформації глядачу. Спортивний костюм для змагань естетично доповнює виступ конкурсанта, допомагає справити бажане враження.

Загалом, будь-який з визначених різновидів сценічного костюма гармонізує загальне враження від того, що відбувається на сцені, як для глядача, так і для митця, або спортсмена.

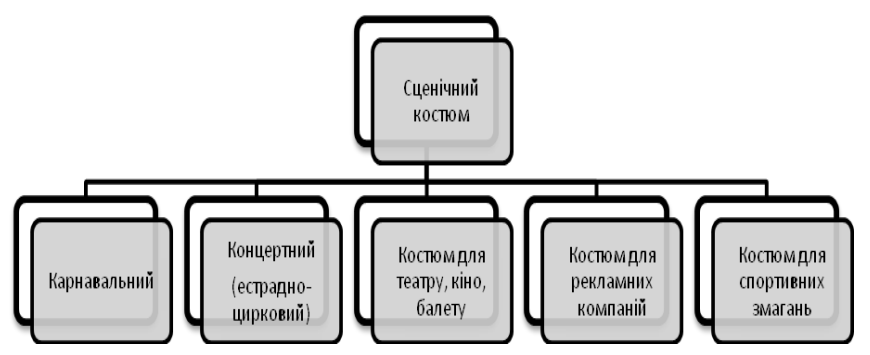

Рис. 4.2. Різновиди сценічного костюму за призначенням

Fig. 4.2. Varieties of stage costume by purpose

На будь-якій з цих сцен використовують костюми, які можна поділити на види, залежно від образотворчих характеристик: національний, історичний, сучасний, ритуально-обрядовий, фантастичний (міфічний), карнавальний (маскарадний), професійний.

Національний костюм відображає особливості культури певної групи людей. Такий одяг завжди свідомо наповнений особливим символічним значенням. На сцені такий костюм 
Деміург: ідеї, технології, перспективи дизайну № 1 (2018) Demiurge: ideas, technologies, perspectives of design № 1 (2018)

ідентифікує персонажа, як такого, що належить до певної національності. Національний костюм також має характеристики приналежності до певного регіону.

Так само, як сучасний костюм відображає суспільний стан сьогодення, історичний костюм відображає специфічні риси того чи іншого періоду буття людства. Костюм кожної людини своїм загальним «модним» видом характеризує відомий період часу, а своїми деталями, манерою носіння визначає характер, смаки, розумове й духовне життя людини, що його носить. Найчастіше історичний костюм використовують у театрі й кіно.

Обрядовий костюм - одяг для проведення певних обрядів, а саме весілля, хрещення та поховання. Цей особливий костюм формувався протягом тисячоліть, регламентуючись не модою, а певними правилами, які вироблені не етикетом, а часом і старовинними забобонами (Бычкова, 2001).

Професійний костюм - це костюм, створений для людини певного роду занять, має специфічні ергономічні та естетичні якості, відповідно до професії. Такі костюми використовують на будь-якій сцені для втілення образу персонажу певної професійної діяльності.

Міфічний, або фантастичний, костюм завжди втілює не існуючу насправді істоту, а вигадану і створену художником. Прикладами таких персонажів є фантастичні персонажі з кіно або мультфільмів, містичні герої міфів і легенд.

Карнавал - це один з видів масових розваг, свято, що відзначають перед початком Великого посту. Воно неодмінно пов'язане з перевдяганнями місцевих жителів, а також туристів у фантастичні, історичні, народні та інші костюми з масками. У цей день головні вулиці міста перетворюються на сцену, де рухається карнавальний хід за певним сценарієм. Масово відбуваються стихійні театралізації, танці, ігри, конкурси. У підготуванні параду беруть участь тисячі професіоналів, а починається це відразу після закінчення попереднього. Приватні спонсори витрачають значну кількість фінансів на костюми (Березовчук, \& Везнесенский, 1998).

Як відомо, кожен костюм є важливим носієм візуальної інформації. Візуальна інформації зчитується і класифікується

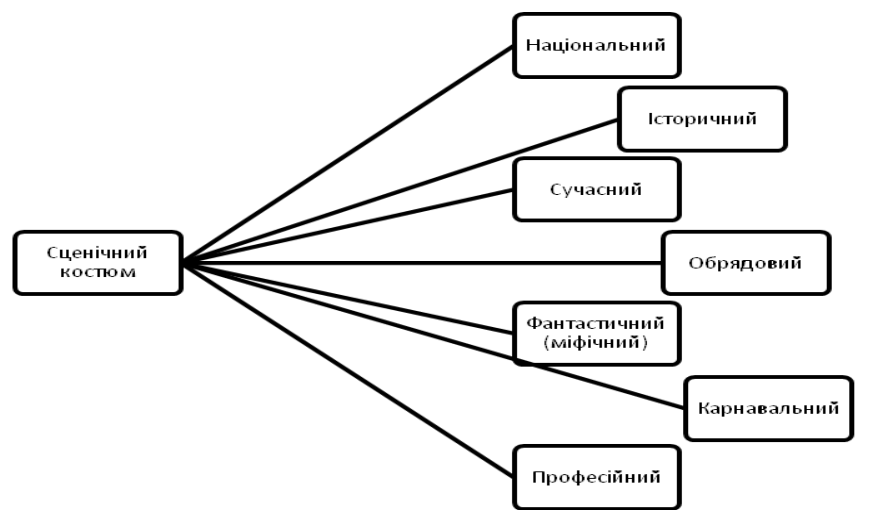

Рис. 4.3. Класифікація сценічного костюму за образотворчими характеристиками

Fig. 4.3. Classification of the stage costume for the visual characteristics 
нами як певна ознака, що наповнюється змістом. Аналізуючи художньо-образні формотворчі домінанти, ми можемо визначати костюм за тими чи іншими ознаками. Пропонуємо класифікувати сценічний костюм за художньо-образними ознаками, які переважать при візуальному спогляданні.

\section{Наукова новизна та практична значимість дослідження

За результатами проведеного дослідження означено місце сучасного сценічного костюма у сучасних мистецьких практиках: театрі, кіно, балеті, естрадно-цирковому мистецтві, спорті, рекламних кампаніях та інших сучасних видовищах, таких як перфоманс, хеппенінг, карнавал. Відтак, уперше здійснено систематизацію різновидів сценічного костюма за призначенням та класифікацію сценічного костюма за образотворчими характеристиками.

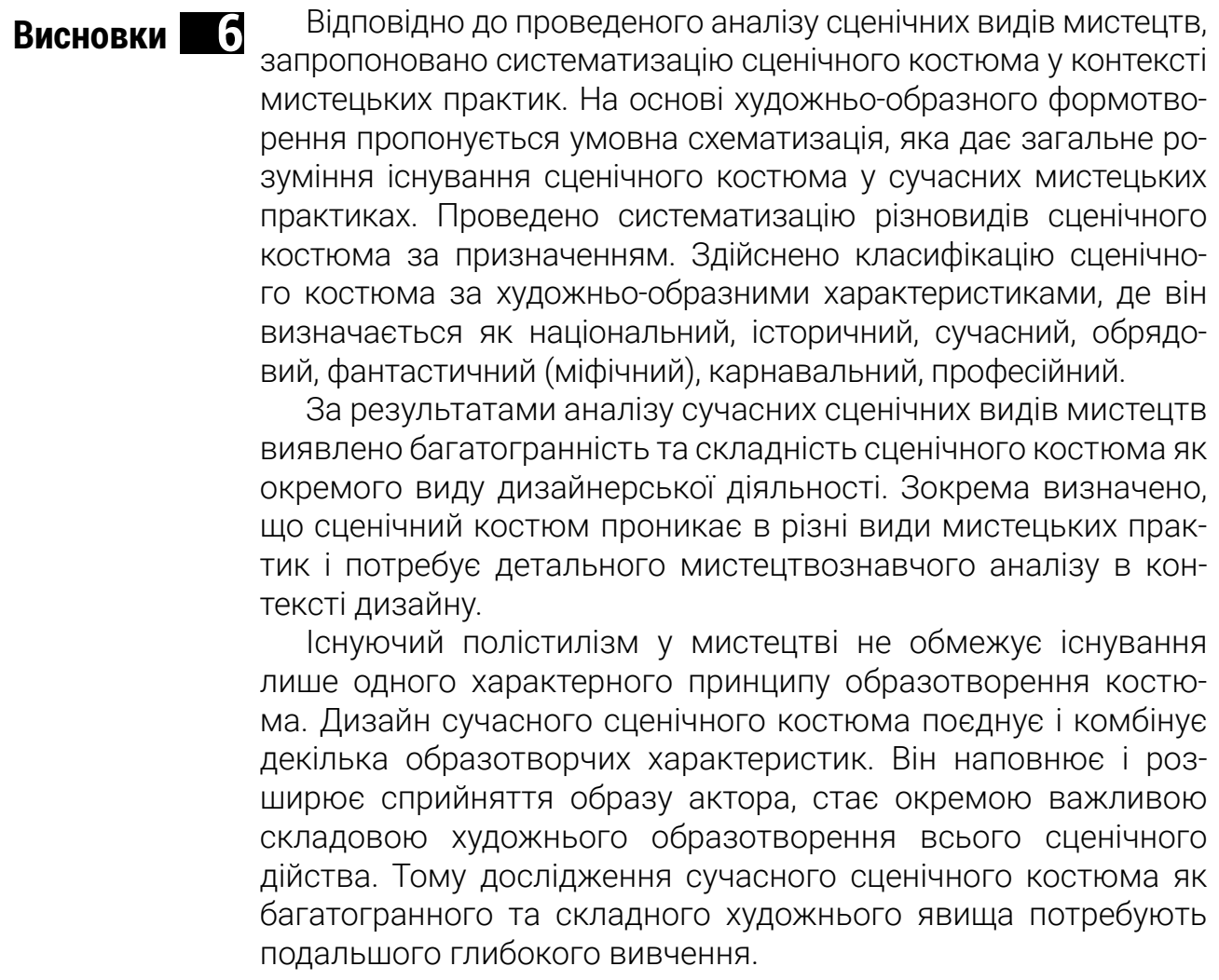

\section{Список посилань}

Андреева, Ю. (2006). Психология имиджа и рекламы: Концепции, технологии, стратегии эффективности. Казань: Центр инновационных технологий.

Березкин, В. (1997). Исскуство сценографии мирового театра: от истоков до середины ХХ века. Москва: Эдиториал.

Березовчук, Л., \& Вознесенский, М. (1998). Маскарад. В Музыкальный Петербург: Энциклопедический словарь, XVIII век (Т. 1, Кн. 2, с. 185-189). Санкт-Петербург: Композитор. 
Бычкова, Н. (2001). Как жили ваши бабушки и прабабушки: Воспоминания. В Российский Архив: История Отечества в свидетельствах и документах XVIII-XX вB. (T. 11, с. 410-443). Москва: Студия ТРИТЭ.

Захаржевская, Р. (2009). История костюма (4-е изд.). Москва: РИПОЛ Классик.

Кибалова, Л., Гербенова, О., \& Ламарова, М. (1987). Иллюстрированная энциклопедия моды. (И.М. Ильинская, \& А.А. Лосева, Пер.). Прага: Артия.

Киреева, Е. (1970). История костюма: Европейские костюмы от античности до XX века. Москва: Просвещение.

Лідер, Д. (2004). Театр для себе. Київ: Факт.

Мерцалова, М. (1993-2001). Костюм разных времен и народов (Т. 1-4). Москва: Академия моды.

Олійник, М. (2017). Український одяг в системі міської культури Києва (друга половина XIX початок XXI століття) [Монографія]. Київ: ІМФЕ.

Почепцов, Г. (2000). Имиджелогия. Киев: Ваклер.

Рыбкин, А. (2014). Журнал «Советский цирк»: Январь 1968 г. [Сообщение форума]. Взято из http://www.ruscircus.ru/forum/index.php?showtopic=24070.

Шандренко, О. (2011). Віртуальний простір моди. Київ: Вид. центр КНУКіМ.

\section{References}

Andreeva, Yu. (2006). Psihologiya imidzha i reklamyi: Kontseptsii, tehnologii, strategii effektivnosti [Psychology of image and advertising: Concepts, technologies, strategies of efficiency]. Kazan: Tsentr innovatsionnyih tehnologiy [in Russian].

Berezkin, V. (1997). Isskustvo stsenografii mirovogo teatra: ot istokov do seredinyi XX veka [The art of scenography of the world theater: from the origins to the middle of the XX century]. Moscow: Editorial [in Russian].

Berezovchuk, L., \& Voznesenskiy, M. (1998). Maskarad [Masquerade]. In Muzyikalnyiy Peterburg: Entsiklopedicheskiy slovar, XVIII vek [Musical Petersburg: Encyclopedic Dictionary, XVIII century] (Vol. 1, Pt. 2, pp. 185-189). St. Petersburg: Kompozitor [in Russian].

Byichkova, N. (2001). Kak zhili vashi babushki i prababushki: Vospominaniya [How your grandmothers and great-grandmothers lived: Memories]. In Rossiyskiy Arhiv: Istoriya Otechestva v svidetelstvah i dokumentah XVIII-XX vV. [Russian Archives: History of the Fatherland in certificates and documents of the XVIII - XX centuries] (Vol. 11, pp. 410-443). Moscow: Studiya TRITE [in Russian].

Kibalova, L., Gerbenova, O., \& Lamarova, M. (1987). Illyustrirovannaya entsiklopediya modyi [IIlustrated encyclopedia of fashion]. (I.M. Ilinskaya, \& A.A. Loseva, Trans.). Prague: Artiya [in Russian].

Kireeva, E. (1970). Istoriya kostyuma: Evropeyskie kostyumyi ot antichnosti do XX veka [Costume history: European costumes from antiquity to the 20th century]. Moscow: Prosveschenie [in Russian].

Lider, D. (2004). Teatr dlia sebe [Theater for yourself]. Kyiv: Fakt [in Ukrainian].

Mertsalova, M. (1993-2001). Kostyum raznyih vremen i narodov [Costume from different times and nations] (Vols. 1-4). Moscow: Akademiya modyi [in Russian].

Oliinyk, M. (2017). Ukrainskyi odiah v systemi miskoi kultury Kyieva (druha polovyna XIX - pochatok $X X I$ stolittia) [Ukrainian clothing in the system of urban culture in Kyiv (second half of the XIX - early XXI century) [Monograph]. Kyiv: IMFE [in Ukrainian].

Pocheptsov, G. (2000). Imidzhelogiya [Imagelogy]. Kiev: Vakler [in Russian].

Ryibkin, A. (2014, December 18). Zhurnal «Sovetskiy tsirk»: Yanvar 1968 g. [Journal «Soviet Circus»: 1968, January]. [Online forum post]. Retrieved from http://www.ruscircus.ru/forum/index. php?showtopic $=24070$ [in Russian].

Shandrenko, O. (2011). Virtualnyi prostir mody [Virtual fashion space]. Kyiv: Publishing Center of KNUCA [in Ukrainian].

Zaharzhevskaya, R. (2009). Istoriya kostyuma [Costume history] (4th ed.). Moscow: RIPOL Klassik [in Russian]. 